Jurnal Kebidanan 13 (02) 128 - 242

Jurnal Kebidanan

http : //www. ejurnal.stikeseub.ac.id

\title{
HUBUNGAN SOSIAL EKONOMI IBU HAMIL DI MASA PANDEMI COVID 19 DENGAN PEMAHAMAN TENTANG PELAYANAN KEBIDANAN DI RB KINASIH, SIDOHARJO, SRAGEN
}

\author{
Rina Harwati ${ }^{1}$, Wahyuningsih ${ }^{2)}$ \\ 1), 2) Program Studi Sarjana Kebidanan dan Profesi Bidan STIKES Estu Utomo \\ E-mail:rinaharwati80@gmail.com,wahyueub2019@gmail.com
}

\begin{abstract}
ABSTRAK
Penurunan jumlah pengunjung ANC sebanyak 67,97\% di RB Kinasih yang pada kenyataannya RB tersebut sudah meningkatkan standart mutu pelayanan kebidanan dan rendahnya pemahaman ibu hamil mengenai pelayanan kebidanan yang mempunyai sosial ekonomi yang berbeda-beda. Berdasarkan latar belakang tersebut, maka tujuan dari peneliti melakukan penelitian ini adalah untuk mengetahui hubungan antara sosial ekonomi ibu hamil dengan pemahaman tentang pelayanan kebidanan. Desain penelitian ini adalah diskripsi korelasi dengan pendekatan cross seksional. Dalam pengambilan sampel, peneliti menggunakan tehnik acidental sampling . Data diambil menggunakan kuesioner. Untuk uji validitas dengan rumus Product Moment dan reliabilitas menggunakan Spearman Brown. Hasil penelitian menunjukkan bahwa ada hubungan antara sosial ekonomi dengan pemahaman tentang pelayanan kebidanan, hal ini dibuktikan dengan hasil perhitungan Chi Square yang lebih besar dari tabel Product Moment sebesar 3,784. Sosial ekonomi ibu hamil sangat berpengaruh terhadap pemahamannya dalam menerima pelayanan kebidanan sehingga diharapkan bidan harus lebih memperhatikan karakteristik ibu hamil dalam memberikan pelayanan karena segala informasi dan tindakan yang diberikan sangat tergantung dari karakteristik ibu hamil tersebut.
\end{abstract}

Kata kunci : Sosial Ekonomi, Ibu Hamil, Pemahaman, Pelayanan Kebidanan

SOCIAL ECONOMIC RELATIONSHIP OF PREGNANT MOTHERS IN THE COVID-19 PANDEMIC WITH UNDERSTANDING OF MIDWIFE SERVICES IN RB KINASIH, SIDOHARJO, SRAGEN

\begin{abstract}
The decrease in the number of ANC such 67,97\% visitors at Kinasih RB, which in fact has increased the quality standard of midwifery services and the low understanding of pregnant women about midwifery services that have different socio-economic. Based on this background, the purpose of the researchers conducting this study was to determine the relationship between the socioeconomic status of pregnant women and their understanding of midwifery services. The design of this research is correlation description with cross sectional approach. In taking the sample, the researcher used the accidental sampling technique. Data were taken using a questionnaire. To test the validity with the Product Moment formula and reliability using Spearman Brown. The results of the study indicate that there is a relationship between socioeconomic and understanding of midwifery services, this is evidenced by the results of the Chi Square calculation which is greater than the Product Moment table such 3,784. Socio-economic conditions of pregnant women greatly affect their understanding of receiving midwifery services, so it is hoped that midwives should pay more attention to the characteristics of pregnant women in providing services because all information and actions provided depend on the characteristics of the pregnant women.
\end{abstract}

Keywords: Socio-Economic, Pregnant Women, Understanding, Midwifery Services

Jurnal Kebidanan, Vol. XIII, No. 02, Desember 2021 


\section{PENDAHULUAN}

Untuk melindungi kepentingan masyarakat atau pasien yang pada umumnya awam terhadap tindakan medis, maka diupayakan agar setiap tindakan medis tidak hanya bertujuan untuk memuaskan pasien tetapi harus sesuai dengan kode etik (Azwar A, 2009). Pemahaman terhadap suatu pelayanan yang bermutu dari sudut pandang pasien sangat dipengaruhi oleh beberapa faktor yaitu faktor sosial, budaya, ekonomi dan pendidikan sehingga akan memunculkan persepsi dan harapan yang berbeda antara pemberi dan pengguna jasa pelayanan. Pasien yang berpendidikan rendah pada umumnya pasrah dan menyerahkan pilihan pengobatannya pada tenaga kesehatan yang mengobatinya. Makin tinggi tingkat pendidikan makin tinggi tingkat kesadaran untuk memperoleh informasi dan hak untuk menerima atau menolak pengobatan yang ditawarkan. Makin tinggi tingkat pendidikan makin tinggi tingkat pemahaman pasien terhadap tindakan yang diterima, sedangkan sosial budaya akan mempengaruhi sikap pasien terhadap tenaga kesehatan. (Abdul, BS, 2000).

$$
\text { Pelayanan kebidanan adalah }
$$
bagian dari pelayanan kesehatan, terutama kesehatan ibu. Untuk memenuhi kebutuhan masyarakat, Departemen Kesehatan Republik Indonesia telah mengambil kebijakan meningkatkan cakupan pelayanan ibu dengan peningkatan kualitas dan kuantitas pertolongan persalinan oleh tenaga kesehatan.

Departemen Kesehatan RI selalu melakukan upaya mempercepat penurunan Angka kematian ibu atau AKI dengan cara mendekatkan pelayanan kebidanan kepada setiap ibu yang membutuhkannya, yaitu dengan menempatkan bidan di desa dan mempermudah bidan untuk praktek mandiri dalam bentuk BPS, RB dan poliklinik. Tetapi juga harus memenuhi syarat - syarat tertentu dan standar yang telah ditetapkan untuk mencapai pelayanan kebidanan yang berkualitas dan terjangkau masyarakat.

Masa pandemik covid 19 ini, merubah kehidupan sebagian masyarakat, banyak masyarakat yang kehilangan pekerjaan sehingga mempengaruhi status ekonomi mereka, sehingga mereka lebih selektif dalam memprioritaskan kebutuhan. Hal yang terjadi adalah, mereka memandang ibu hamil tidak harus selalu datang periksa ANC selama kondisi kehamilannya baik-baik saja.

Rumah bersalin Kinasih yang beralamatkan di Sidoharjo, Sragen merupakan salah satu Rumah bersalin yang sudah cukup lama dalan 
memberikan jasa pelayanan sejak tahun 2008. Sejak tahun 2008 Rumah bersalin ini sudah mengatasi perubahan perubahan global yang terjadi, Dalam kenyataan didapatkan data yang kurang menguntungkan bagi Rumah bersalin Kinasih selama masa pandemi yaitu penurunan jumlah kunjungan ibu hamil dari 2.352 kunjungan menjadi 3.523 pada tahun 2020 atau menurun $67,97 \%$. Ada $10 \%$ dari $25 \mathrm{ibu}$ hamil dengan karakteristik yang berbeda - beda didapatkan data dari para ibu hamil mengeluarkan pendapat bahwa setelah RB Kinasih semakin lengkap, biaya nya pun juga bertambah. Padahal apabila dilihat kembali Rumah bersalin Kinasih sudah memenuhi kualifikasi sebuah Rumah bersalin yang baik dari tingkat keprofesionalismenya maupun standar pelayanan.

Dengan demikian perlu diadakan penelitian untuk mengumpulkan pendapat - pendapat dari para ibu hamil yang melakukan kunjungan ANC di Rumah bersalin kinasih tersebut secara sistematis karena pasien merupakan sumber informasi yang sangat penting.

\section{METODE}

Desain penelitian yang digunakan pada penelitian ini adalah deskriptif korelasi dengan pendekatan cross sectional yaitu untuk melihat hubungan antara sosial ekonomi ibu hamil dengan tingkat pemahaman tentang pelayanan kebidanan dengan melakukan pengukuran variabel sesaat. Populasi dalam penelitian ini adalah semua ibu hamil yang melakukan kunjungan ANC di Rumah bersalin Kinasih, Sidoharjo, Sragen Rata - rata dalam satu bulan ada 60 ibu hamil yang melakukan kunjungan. Dalam penelitian ini cara pengambilan sampel menggunakan cara accidental sampling. Variabei independen adalah sosial ekonomi keluarga. Dan variabel dependennya adalah pemahaman tentang pelayanan kebidanan Dalam penelitian ini, instrumen yang digunakan adalah kuesioner yang berisi 25 item pertanyaan. Uji validitas menggunakan rumus korelasi yang dikemukakan oleh Pearson yaitu rumus korelasi Product Moment Uji reliabilitas menggunakan rumus Spearman Brown. Untuk mengetahui atau melihat hubungan antara sosial ekonomi ibu hamil dengan pemahaman tentang pelayanan kebidanan digunakan uji statistik Chi-Square

\section{HASIL DAN PEMBAHASAN}

Hubungan antara Ekonomi Keluarga Ibu Hamil dengan Pemahaman Tentang Pelayanan Kebidanan. 
Tabel 1. Distribusi Responden Menurut Usia Ibu Hamil

\begin{tabular}{ccc}
\hline Usia (Tahun) & $\mathbf{n}$ & $\mathbf{( \% )}$ \\
\hline$\leq 20$ & 18 & 24,4 \\
$21-35$ & 30 & 55,6 \\
$>35$ & 12 & 20 \\
\hline Jumlah & $\mathbf{6 0}$ & $\mathbf{1 0 0}$ \\
\hline
\end{tabular}

Sebagian besar responden berusia rentang antara 21-35 tahun yaitu sebanyak 25 responden $(55,6 \%)$. Yang merupakan usia paling ideal bagi seorang untuk hamil.
Tabel 1. Distribusi Responden Menurut Pekerjaan Ibu Hamil

\begin{tabular}{|c|c|c|}
\hline Pekerjaan & $\mathbf{n}$ & $(\%)$ \\
\hline Pegawai Negeri & 8 & 14,4 \\
\hline IRT & 37 & 65,6 \\
\hline Pegawai Swasta & 15 & 20 \\
\hline Jumlah & 60 & 100 \\
\hline \multicolumn{3}{|c|}{$\begin{array}{l}\text { Dari tabel diatas sebagian besar } \\
\text { responden sebagai Ibu Rumah Tangga } \\
\text { sebanyak } 37 \text { responden atau } 65,5 \% \text {. } \\
\text { Merupakan faktor pendukung untuk } \\
\text { status ekonomi yang rendah. }\end{array}$} \\
\hline
\end{tabular}

Tabel 3.

Hubungan antara Ekonmi Keluarga Ibu Hamil dengan Pemahaman Tentang Pelayanan Kebidanan

\begin{tabular}{|c|c|c|c|c|}
\hline Komponen & Fo & $\mathbf{F e}$ & $(\text { fo-fe })^{2}$ & $(\mathbf{f o}-\mathbf{f e})^{2} / \mathbf{f e}$ \\
\hline > UMR - Paham & 11 & $(23 \times 33) / 60=12,65$ & 2,7225 & 1,215 \\
\hline > UMR - Tidak paham & 12 & $(23 \times 27) / 60=10,35$ & 2,7225 & 0,263 \\
\hline$<$ UMR - Paham & 15 & $(37 \times 27) / 60=16,65$ & 2,7225 & 0,263 \\
\hline$<$ UMR - Tidak paham & 22 & $(37 \times 33) / 60=20,35$ & 2,7225 & 2,133 \\
\hline & & $\mathrm{Jml}$ & & $x^{2}=3,874$ \\
\hline
\end{tabular}

Dari tabel diatas menunjukkan bahwa responden yang mempunyai penghasilan dibawah UMR tidak paham mengenai pelayanan kebidanan sebesar 2,133 sebanyak 22 responden.

\section{Pembahasan}

Dari hasil uji hipotesis didapatkan $\mathrm{x}^{2}$ hitung 3,874 dan $\mathrm{x}^{2}$ tabel dengan dk 1 dan $\alpha$ 0,05 adalah 3,841 sehingga $\mathrm{x}^{2}$ hitung $>\mathrm{x}^{2}$ tabel maka hipotesis diterima yaitu adanya hubungan antara ekonomi keluarga ibu hamil dengan pemahaman tentang pelayanan kebidanan.
Menurut Abdul BS (2002) masyarakat yang berpenghasilan rendah akan memahami bahwa pelayanan yang baik adalah yang murah dan terjangkau masyarakat, yang berpenghasilan lebih akan memahami bahwa pelayanan dengan peralatan dan pengobatan mahal adalah pelayanan yang baik.

Menurut Sulistyawati (2009), pekerjaan seseorang akan menggambarkan aktivitas dan tingkat kesejahteraan ekonomi yang akan didapatkan. Ibu yang bekerja, mempunyai tingkat pengetahuan yang lebih baik daripada ibu yang tidak 
bekerja. Karena pada ibu yang bekerja akan lebih banyak memiliki kesempatan untuk berinteraksi dengan orang lain, sehingga mempunyai banyak peluang juga untuk mendapatkan informasi seputar keadaannya.

Status ekonomi seseorang juga akan menentukan tersedianya fasilitas yang diperlukan untuk kegiatan tertentu, sehingga status sosial ekonomi akan mempengaruhi pengetahuan seseorang. Status ekonomi adalah kedudukan seseorang atau keluarga di masyarakat berdasarkan pendapatan per bulan (Purwoastuti \& Walyani, 2015). Hal ini mendukung pendapat Pasaribu (2005) bahwa ibu hamil yangbekerja bukan saja mempunyai sumber penghasilan untuk melakukan pemeriksaan.

Hal ini sesuai dengan kenyataan pada saat ini, masa pandemi membuat banyak masyarakat yang mempunyai penghasilan dibawah standar. Dalam kehidupannya masyarakat tersebut akan lebih mengutamakan kebutuhan keluarga dibandingkan untuk berobat. Maka dengan penghasilan yang semakin tinggi akan mempengaruhi pemahaman seseorang bahwa pelayanan yang baik tidak hanya terfokus pada biaya dan terjangkaunya pelayanan tersebut, tapi lebih terfokus dapa hasil pengobatan dan peralatan yang digunakan tenaga kesehatan dalam mengobati pasien. Dan menurut Umayah (2010), bahwa rendahnya penghasilan seseorang atau keluarga meningkatkan hambatan untuk mendapatkan prioritas kesehatan dalam urutan lebih tinggi daripada prioritas kebutuhan pokok, Sehingga hal ini lah yang menyebabkan penurunan jumlah kunjungan ANC di RB Kinasih.

\section{PENUTUP}

Ada hubungan antara ekonomi keluarga responden dengan pemahaman tentang pelayanan kebidanan, ditunjukkan dengan $\mathrm{x}^{2}$ hitung > $\mathrm{x}^{2}$ tabel yaitu $3,874>3,841$. Diharapkan kepada Bidan saat melakukan asuhan kehamilan tidak hanya terfokus pada keluhan atau kehamilan pasien saja, tapi juga menggali lebih dalam lagi mengenai karakterisrik pasien atau ibu hamil tersebut. Karena untuk pemahaman yang benar tentang asuhan yang dilakukan Bidan, ibu hamil tersebut sangat tergantung dengan karakteristiknya masing-masing. Bidan harus menjelaskan dan memberitahu segala asuhan ayng akan diberikan kepada ibu hamil yang mempunyai karakteristik yang berbeda-beda sehingga ibu hami tersebut mempunyai pemahaman yang benar dan tidak mempunyai pendapat negatif tentang pelayanan yang diterima. 
DAFTAR PUSTAKA

Abdul, BS. (2010). Buku Acuan Nasional Pelayanan Kesehatan Maternal dan Neonatal. Cetakan pertama. Jakarta: YBP-SP

(2002). Buku Panduan

Praktis Pelayanan Kesehatan Maternal dan Neonatal. Cetakan pertama. Jakarta: YBP-SP

Arikunto, Suharsimi. Manajemen Penelitian. Cetakan Kedua. Jakarta: Rineka Cipta

Azwar, Azrul. (2009). Pengantar Adsministrasi Kesehatan. Edisi ketiga. Jakarta: Binarupa Aksara

Budiarto, Eko. (2012). Biostatistika Untuk Kedokteran dan Kesehatan Masyarakat. Cetakan pertama. Jakarta : Buku Kedokteran EGC

Ingewati, C. 2014. Ibu Mengandung dengan Perasaan Cemas Selama Hamil Normalkah. http://mutiarabijaksana.com/2014 106/2 7/ibu-mengandung-denganperasaan- cemas-normalkah/ (Diakses pada tanggal 10 September 2016)

Komariyah. 2014. Di Puskesmas, B. B. K. S.Hubungan antara Dukungan Keluarga dengan Pemahaman Ibu Hamil tentang Pemeriksaan
Antenatal Care.

http://perpusnwu.web.id/karyailm iah/d ocuments/3628.pdf (Diakses padatanggal 11 Juni 2016)

Manuaba, IBG. (2018). Ilmu Kebidanan, Penyakit Kandungan dan Keluarga Berencana. Cetakan Pertama. Jakarta: Buku Kedokteran EGC

Notoatmodjo, Soekidjo. (2019). Pendidikan dan Perilaku Kesehatan. Cetakan pertama. Jakarta: Rineka Cipta

Pasaribu, S. 2005. Pengaruh Faktor Sosial Budaya dan Sosial Ekonomi Terhadap Pemeriksaan Kehamilan di Desa Bandar Sakti Puskesmas Rantau Laban Kota Bukit Tinggi. Skripsi. Universitas Sumatera Utara Medan http://repository.usu.ac.id/handle/ $\underline{1234} \underline{56789 / 14747}$ (Diakses pada tanggal 11Juni 2016)

Sofyan, Mustika. (2013). Lima Puluh Tahun IBI, Bidan Menyongsong Masa Depan. Cetakan kedua. Jakarta: PP IBI

Wijono, Wibisono, dkk. (2012). Standar Pelayanan Kebidanan. Jakarta: IBI- Depkes RI 